\title{
Research on Cultivating Mode of Economics and Management Undergraduates' Innovation and Entrepreneurship Practical Skills
}

\author{
Bing Su${ }^{1, a}$, Yang $\mathrm{Li}^{1, \mathrm{~b}}$, Xiaoyi Lan ${ }^{1, \mathrm{c}}$ \\ ${ }^{1}$ School of Economics and Management, Xi'an Technological University, Xi'an, 710032, China \\ aemail: subing684@sohu.com, bemail:lyon0306@sina.com, 'email:lanxiaoyi2004@163.com
}

Keywords: innovation and entrepreneurship; practical skills; cultivating mode

\begin{abstract}
With the deepening and development of the higher education system reform in China, the cultivation of economics and management undergraduates' innovation and entrepreneurship practical skills is very important for college students to cultivate talents. In this paper, taking the undergraduates of economics and management as the pointcut, based on the status quo' analysis of cultivating mode of innovation and entrepreneurship practical skills, it constructs the three-level cultivating path, which is the cultivation of basic practical skills, the cultivation of specialty innovation and entrepreneurship skills and the cultivation of comprehensive innovation and entrepreneurship skills.
\end{abstract}

\section{Introduction}

In the new economic era of information and knowledge, the "strategy of innovation-driven development" has been proposed in our country and the innovation and entrepreneurship education in colleges has become the key factor to achieve national innovation-driven strategy. The construction of innovation-oriented country is the guarantee of scientific and technological strength, and the most important is to cultivate innovative and entrepreneurial talents. Therefore, as the basic premise of innovative and entrepreneurial talents cultivation, building a perfect innovation and entrepreneurship education system has become a top priority. Innovation and entrepreneurship education is the inevitable requirement and effective way to adapt to the development of the times under the background of information and globalization.

However, the existing cultivating mode of economics and management undergraduates' innovation and entrepreneurship skills often pays attention to the cultivation of basic practical skills. After the innovation and entrepreneurship concept has been proposed, its education is implemented. The consequence is that students' specialty characteristics are not integrated into the cultivation of economics and management's innovation and entrepreneurship skills. Also, it does not achieve the cross-specialty integration of various specialties.

According to research and analysis for cultivating mode of economics and management undergraduates' innovation and entrepreneurship practical skills, the three-level cultivating path is put forward, which is basic practical skills, specialty innovation and entrepreneurship skills and comprehensive innovation and entrepreneurship skills. Firstly, this path cultivates students' basic practical skills through the curriculum design of disciplinary basic courses and related experiments, mainly to cultivate students' innovation and entrepreneurship consciousness. Secondly, it cultivates students' specialty innovation and entrepreneurship practical skills by students' specialty practices. Finally, it makes students master cross-specialty practical skills to achieve the integration of cross-specialty practical skills. The objective is ultimately cultivating applied talents with a high level of innovation and entrepreneurship practical skills through the gradual three-level development. It designs evaluation index system to evaluate and feed back the cultivating effect. If it has not achieved the expected, it will continue to adjust the cultivating path, so as to better guide the implement of innovation and entrepreneurship practical skills education. 


\section{The cultivating mode problems of economics and management undergraduates' innovation} and entrepreneurship practical skills

The cultivating mode problems of economics and management undergraduates' innovation and entrepreneurship practical skills are found out through the investigation and analysis of teaching mode and the current situation of social enterprises for these skills.

\subsection{Innovation and entrepreneurship is not integrated into the basic practical skills cultivation.}

The teaching method of basic courses, such as management, marketing, is mainly based on the traditional theory teaching, and the related curriculum design is to cultivate students' basic skills. However, the curriculum design of these courses is the main demonstration or validation. It is just to demonstrate or validate the studied theory and does not introduce the cultivation of students' innovation and entrepreneurship consciousness, which leads to students' weak innovation consciousness and can not meet the needs of enterprises high level talents.

For example, students learn about the basic theoretical knowledge in the course of statistics. There will be the curriculum design about 1 week after the end of the course. The curriculum design mainly demonstrates or validates the theory with software, no relevant experimental design to enable students to participate, which does not integrate the innovation elements into the basic practical skills cultivation and guide the students' entrepreneurial thinking.

\subsection{Existing practical skills cultivation does not highlight the students' specialty characteristics.}

The existing cultivating mode of economics and management undergraduates' practical skills pays attention to the cultivation of fine talents and systemically studies the theory and practice of skills based economy and enterprise management. It does not highlight students' specialty characteristics and leads to students master the practical skills of similar specialty characteristics.

For example, the accounting students will learn basic theoretical knowledge and skills in statistics, like the use of EXCEL or SPSS. It's not involved in specialty knowledge. All of this, each specialty will learn the similar practical skills, not highlighting the characteristics of their own.

\subsection{Existing practical skills cultivation does not achieve cross-specialty skills integration.}

The cultivation of each specialty practical skills is independent according to their own training program. And it does not achieve cross-specialty skills integration, which is not conducive to the development of students' comprehensive ability. The result is influential in the cultivation of innovation and entrepreneurship practical skills for applied talents.

For example, human resource management students only master the practical skills related to their major, like human resources quality evaluation, salary management and management for discussion, etc. It is not related to other relevant practical skills such as business negotiation of marketing, and does not achieve cross-specialty skills integration.

\section{Construction of economics and management undergraduates' cultivating mode of innovation and entrepreneurship practical skills}

Economics and management undergraduates' cultivating mode of innovation and entrepreneurship practical skills is a system, which not only motivates college students' innovative thinking and consciousness but also combine the professional characteristics of economics and management with the innovation and entrepreneurship practical skills. 


\subsection{The cultivating mode of innovation and entrepreneurship practical skills}

The paper has constructed highlighting the characteristics' cultivating mode of economics and management undergraduates' innovation and entrepreneurship practical skills. This cultivating mode is mainly composed of four parts, the cultivating objectives, the cultivating path, the cultivating effect evaluation and the corresponding feedback and continuous improvement. The objective is the cultivating mode of three-level cultivating path to break the traditional culture of the economics and management "specialization", link theory and practice, achieve cross-specialty skills integration of innovation and entrepreneurship practical skills, and cultivate applied talents with high innovation practical ability. Finally, the evaluation index system is designed to evaluate and feed back the cultivating effectiveness. If not achieving the expected effect, it needs to adjust the cultivating path.

\subsubsection{Cultivating objective}

The cultivating mode of economics and management undergraduates' innovation and entrepreneurship practical skills aims to cultivate high-level applied talents of innovation and entrepreneurship practical ability.

\subsubsection{Cultivating path}

The cultivating path includes three steps and it aims to achieve the cultivating objectives through the cultivation of basic practical skills, specialty innovation and entrepreneurship skills and comprehensive innovation and entrepreneurship skills.

(1) The cultivation of basic practical skills

According to the cultivation for the economics and management undergraduates, the courses not only are basic curriculum courses, but also need to set up such as innovation and entrepreneurship practical courses. And it needs to add innovative content and adopt new teaching methods to enable students to master the basic practical skills on cultivating students' consciousness and thinking of innovation and entrepreneurship.

(2) The cultivation of specialty innovation and entrepreneurship skills

Based on the students' ability of basic practical skills, the school sets up the training laboratory to cultivate corresponding ability of specialty innovation and entrepreneurship skills. For example, accounting manual simulation laboratory creates the basic conditions for accounting students to fully learn and master accounting specialized knowledge and skills in a relatively short period.

(3) The cultivation of comprehensive innovation and entrepreneurship skills

In order to cultivate comprehensive talents, students should not only have the basic and specialized knowledge, but also need to learn and communicate with other specialties. Therefore, it is very important to cultivate the comprehensive practical ability. To this end, the school sets up a cross-specialty comprehensive training center of innovation and entrepreneurship.

\subsubsection{The cultivating effect evaluation}

The cultivating effect evaluation of innovation and entrepreneurship practical skills will be divided into four aspects, which are the teachers' specialized quality, the students' knowledge level, the students' innovative ability and the evaluation of employer.

(1) The teachers specialized quality is composed of teachers innovative spirit v teaching methods and morality standard.

(2) The students knowledge level includes basic knowledge level、 professional knowledge level and innovative knowledge level, etc.

(3) The students innovative ability is composed of innovative consciousness and thinking 、 innovative skills and extracurricular innovative activities, etc.

(4) The evaluation of employer is composed of graduates practical innovation ability , work 
performance and coordination skills, etc.

\subsubsection{The corresponding feedback and continuous improvement}

In accordance with the cultivating path to complete the students' cultivation of innovation and entrepreneurship practical skills, it needs to evaluate and feed back the cultivating effect. If the cultivating results are not expected, then the cultivating path is adjusted, so that the whole cultivating process is more perfect and ultimately achieve the expected target.

\subsection{The cultivating ways of innovation and entrepreneurship practical skills}

(1) The cultivating mode of innovation and entrepreneurship practical skills is included in the economics and management undergraduates cultivating program, so that students can be aware of the importance of innovation and entrepreneurship education.

(2) To explore and implement the teaching methods of "industrial-academic-research" cooperation, establishing advanced training bases and improving the practical teaching methods can cultivate students' innovative spirit and practical ability. The school can establish practical base and various types of enterprises and manufacturers in order to let students touch the actual production and the combination of professional knowledge and practice to improve innovative and practical ability.

(3) The school should hold and organize various academic competitions, like Challenge Cup, and constantly improve the innovative ability. Then they should strengthen the students' guidance and motivate students to participate in the scientific research and innovation activities positively.

\section{Conclusions}

In order to make the university become the birthplace of innovative knowledge and the cradle of cultivating and producing high-quality innovative talents, especially the economics and management undergraduates have the innovation and practical skills, it is necessary to make the cultivating mode of innovation and practical skills more perfect. This is to cultivate high-quality talents to meet the requirements of the society.

\section{Acknowledgements}

In this paper, this research is sponsored by Humanities and Social Science Talent Plan, Higher Education Teaching Reform Project of Shaanxi under Grant 15BZ41 and Teaching Reform Project of Xi'an Technological University under Grant 15JGZ04 and Grant 16JGY19.

\section{References}

[1] Liao X R, Yang Z M. Cultivation of College Students' Innovative Consciousness and Innovative Ability [J]. Education Exploration, 2000(5):10-12. (In Chinese)

[2] Zhao W Q, Wang Y. Research on the Innovation Ability of Economic and Management College Students [J]. MODER BUSIBESS, 2010(15):280-281. (In Chinese)

[3] Tong X L. Research on Innovation and Entrepreneurship Education System of Research University [D].Wuhan: Wuhan University of Technology, 2012 (In Chinese)

[4] Yan N. Exploration and Practice on Innovative Personnel Training Model in Economic and Management Specialty [J]. Journal of Educational Institute of Jilin Province, 2012,09(28):35-36.(In Chinese)

[5] Liu D L, Ma L Y, Hao P F. Study on the Training Pattern of Undergraduates Majoring in Economics and Management [J].Journal of Agricultural University of Hebei(Agriculture and 
Forestry Education Edition), 20091,06(11):142-144. (In Chinese)

[6] Jiang B Y. Exploration and Practice of Innovative Talents Training Mode of Economics and Management [J]. Career Horizon, 2005(20):42-43. (In Chinese) 